Research Article

\title{
Bond Behavior of CRACFST Columns after Exposure to Elevated Temperatures
}

\author{
Peng $\mathrm{Hu}^{1,2}$ and Jiong-Feng Liang $\mathbb{D}^{2}$ \\ ${ }^{1}$ College of Civil Engineering, Xi'an University of Architecture \& Technology, Xi'an, Shanxi 710055, China \\ ${ }^{2}$ Faculty of Civil \& Architecture Engineering, East China University of Technology, Nanchang, Jiangxi 330013, China
}

Correspondence should be addressed to Jiong-Feng Liang; jiongfeng108@126.com

Received 21 March 2019; Revised 13 May 2019; Accepted 12 June 2019; Published 1 July 2019

Academic Editor: Xuemei Liu

Copyright (c) 2019 Peng Hu and Jiong-Feng Liang. This is an open access article distributed under the Creative Commons Attribution License, which permits unrestricted use, distribution, and reproduction in any medium, provided the original work is properly cited.

\begin{abstract}
The bond behavior of post-heated circular recycled aggregate concrete-filled steel tube (CRACFST) columns is experimentally investigated in this paper. A total of 24 heated push-out CRACFST specimens are prepared; at the same time, 3 unheated specimens are also prepared and tested for comparison. This paper investigates the effects of five variable parameters, namely, temperature, exposure period, recycled coarse aggregate (RCA) replacement ratio, concrete strength, and interface length-todiameter ratio, on the bond stress-slip curves and bond strength. The results show that the push-out CRACFST specimens exhibit some differences in bond stress-slip curves at both ambient and high temperature. The bond strength increases with increasing temperature. Other parameters also have influence to some extent. On the basis of a regression analysis of the experimental data, a revised bond strength model is proposed to predict the post-heated bond behavior between recycled aggregate concrete and circular steel tube.
\end{abstract}

\section{Introduction}

The use of recycled aggregate concrete (RAC) can reduce the energy consumption and save the available natural resources [1-7]. However, for the relatively poorer mechanical properties of RAC, they are generally limited to applications that do not require high structural performance. To fix such drawback, recycled aggregate concrete-filled steel tube columns were then developed, behavior of which were then studied by several researchers $[8,9]$. For example, Wang et al. [10] investigated the effect of the strength of the parent waste concrete on the creep behavior of recycled aggregate concrete-filled steel tubes (RACFST), and a creep model for RACFST was provided. Li et al. [11] explored the impact performances of steel tube-confined recycled aggregate concrete (STCRAC) after exposure to elevated temperatures. Chen et al. [12] experimentally studied the mechanical behavior of normal-strength recycled aggregate concretefilled steel tubes under combined loading.
It is well known that the bond behavior between steel tube and core concrete influenced the composite effect of CFST columns, which were studied by several researchers $[13,14]$. For instance, Chen et al. [15] investigated the influence of different values of height-to-diameter ratio, diameter-to-thickness ratio, and concrete strength on the bond-slip behavior of concrete-filled stainless steel circular hollow section tubes. Tao et al. [16] studied bond performance between the steel tube and concrete in concrete-filled steel tubular columns after exposed to ISO 834 standard fire. Chen et al. [17] investigated the bond behavior between steel tube and recycled aggregate concrete (RAC) at room temperature, and the theoretical analytical model for interfacial bond shear transmission length was established.

As discussed above, it can be known that the bond behaviors of nature concrete-filled steel tube columns are extensively studied in the previous studies, of which RACFST columns, however, are barely investigated. Especially, the bond behavior of RACFST columns after exposure 
to high temperatures has not been reported till now. Thus, the objective of this study is to investigate the bond behavior for CRACFST columns after exposure to high temperatures. The results can be used as a theoretical and experimental basis for fire prevention design and fire safety assessments of recycled aggregate concrete structures.

\section{Experimental}

2.1. Specimen Design. A total of 27 circular RACFST pullout specimens, including 24 heated and 3 unheated at ambient temperature (i.e., $20^{\circ} \mathrm{C}$ ) are prepared. The main variables investigated in the test are (a) temperature $T\left(T=20^{\circ} \mathrm{C}\right.$, $200^{\circ} \mathrm{C}, 400^{\circ} \mathrm{C}, 600^{\circ} \mathrm{C}$, and $800^{\circ} \mathrm{C}$ ); (b) exposure period $t$ $(t=30 \mathrm{~min}, 60 \mathrm{~min}$, and $120 \mathrm{~min})$; (c) RCA replacement ratio $r(r=0 \%, 50 \%$, and $100 \%)$; (d) concrete strength (C30 and $\mathrm{C} 40)$; and (e) interface length-to-diameter ratio $(L / D=2.3$ and 3.6, where $L$ is the length of the steel-concrete interface and $D$ is the diameter of the concrete section). Details of the specimens are presented in Table 1.

2.2. Material Properties. The design of the concrete mix and cube concrete strength $\left(f_{\mathrm{cu}}\right)$ are given in Table 2 , which are made up of cement, natural fine aggregate, natural coarse aggregate (NCA), recycled coarse aggregate (RCA), and water. Three RCA replacement ratios, i.e., 0 , 50, and 100\%, and two types of concrete, i.e., C30 and C40, are included, where the RCA replacement ratio indicates the proportion of natural coarse aggregate replaced by RCA. In this test, common Portland cement type 32.5R for C30 and type 42.5R for C40, in according with the Chinese standard GB 1751999, are used. The fine aggregates are river sand with fineness modulus of 2.7 and $0.6 \%$ moisture content. The NCA size fraction used is $5-20 \mathrm{~mm}$. The RCA is obtained from waste concrete which is crushed by a jaw crusher and brought from the reclamation depot in Nanchang, PR China, which is in the range $5-20 \mathrm{~mm}$. The physical properties of RCA are shown in Table 3. The yield strength, ultimate tensile strength, and modulus of elasticity of circular steel tubes (Q235) are $273 \mathrm{MPa}, 375 \mathrm{MPa}$, and $201 \mathrm{GPa}$, which are used in this pullout tests.

2.3. Heat Treatment. To evaluate the effect of high temperatures on the bond properties between steel tubes and RCA concrete, 24 specimens are heated by exposing them to heat in a high-capacity electrical furnace with a maximum heating temperature of $1200^{\circ} \mathrm{C}$. The temperature is increased to a prescribed temperature level with a rate of $5^{\circ} \mathrm{C} / \mathrm{min}$ and then maintained at this level for a required period (i.e., $30 \mathrm{~min}, 60 \mathrm{~min}$, or $120 \mathrm{~min}$ ). The pullout tests of the heated specimens are conducted after they are cooled to ambient temperature. For comparison, 3 unheated specimens at ambient temperature (i.e., $20^{\circ} \mathrm{C}$ ) are also tested.

2.4. Testing. A YAW-3000 microcomputer controlled electrohydraulic servo tester is used to conduct the pullout test, which is shown in Figure 1. The pullout CRACFST specimens are set up vertically with the air gap at the bottom of the testing machine. A layer of sand is spread on the top surface of the CRACFST specimens, and then a steel block with a cross section slightly smaller than the inside diameter of steel tube is placed on the top of the CRACFST specimens. This assured the load is applied only on the recycled aggregate concrete core and allow the recycled aggregate concrete core to be pushed out during testing. All specimens are tested under a displacement control rate of $0.5 \mathrm{~mm} / \mathrm{min}$. The linear variable displacement transducer (LVDT) is used to measure the relative slip between the steel tube and recycled aggregate concrete core. The test is terminated when the load stays almost unchanged with the increase of the slip.

\section{Results and Discussion}

3.1. Test Observations and Results. There is no visible change in the appearance of steel tubes, and no cracks appear in the push-out test. All the push-out RCA concrete specimens exhibit relatively ductile behaviors. Initially, the slip between the interface of recycled aggregate concrete and steel tubes is found to increase linearly. When the load increases, the slip starts to develop rapidly. Then, the push-out RCA concrete specimens fail with a breaking sound, after which the load drops to a certain level and remains almost unchanged. A typical failure mode of pullout specimens is shown in Figure 2. The experimental results of the pullout specimens, including compressive strength $f_{\mathrm{cu}}$ of RAC, peak load $P_{\mathrm{u}}$, peak bond stress $\tau_{\mathrm{u}}$, and unloaded end slip, are summarized in Table 3 . The bond strength can be calculated by

$$
\tau_{\mathrm{u}}=\frac{P_{\mathrm{u}}}{A}
$$

where $\tau_{\mathrm{u}}$ is the bond strength between the concrete and steel tube, $P_{\mathrm{u}}$ is the peak load, and $A$ is the contact area along the embedment length.

3.2. Effect of High Temperature. The effect of temperature $T$ on stress-slip $(\tau-S)$ curves is given in Figure 3. It can be seen that temperature influences the shape of $\tau$-S curves. For unheated specimens, the curves reach the peak bond strength followed by a relatively short and steep descending branch before reaching a stable branch, which of the heated specimens. However, it generally exhibits a relatively long and gentle descending branch. Figure 4 shows the influence of temperature on the bond strength $\tau_{\mathrm{u}}$. Results suggest that the bond strength increases with the increase in temperature. For the RCA replacement ratio of $0 \%$, the bond strength increases $44.6 \%, 105.2 \%, 131.8 \%$, and $203.1 \%$ for $\mathrm{C} 11, \mathrm{C} 12$, $\mathrm{C} 7$, and $\mathrm{C} 13$ specimen for $200^{\circ} \mathrm{C}, 400^{\circ} \mathrm{C}, 600^{\circ} \mathrm{C}$, and $800^{\circ} \mathrm{C}$, respectively. The bond strength of specimens with the RCA replacement ratio of $50 \%$ or $100 \%$ is similar to that with the RCA replacement ratio of $0 \%$ after exposure to high temperatures. The bond strength is $146.6 \%, 215.4 \%, 237.6 \%$, and $339.3 \%$ for specimens with the RCA replacement ratio of $50 \%$, and $146.4 \%, 217.5 \%, 256.3 \%$, and $364.9 \%$ for specimens with the RCA replacement ratio of $100 \%$ at $200^{\circ} \mathrm{C}, 400^{\circ} \mathrm{C}$, 
TABLE 1: Summary of test specimens and results.

\begin{tabular}{|c|c|c|c|c|c|c|c|c|}
\hline No. & $D \times t_{\mathrm{s}} \times L_{\mathrm{e}}(\mathrm{mm})$ & $T\left({ }^{\circ} \mathrm{C}\right)$ & $t(\min )$ & $r(\%)$ & Concrete type & $L_{\mathrm{e}} / D$ & $\tau_{\mathrm{u}}(\mathrm{MPa})$ & $S_{\mathrm{u}}(\mathrm{mm})$ \\
\hline $\mathrm{C} 1$ & $114 \times 3 \times 410$ & 600 & 120 & 0 & C30 & 3.6 & 1.28 & 1.35 \\
\hline $\mathrm{C} 2$ & $114 \times 3 \times 410$ & 600 & 120 & 50 & $\mathrm{C} 30$ & 3.6 & 1.32 & 1.37 \\
\hline $\mathrm{C} 3$ & $114 \times 3 \times 410$ & 600 & 120 & 100 & $\mathrm{C} 30$ & 3.6 & 1.51 & 1.23 \\
\hline $\mathrm{C} 4$ & $114 \times 3 \times 410$ & 600 & 120 & 0 & $\mathrm{C} 40$ & 3.6 & 1.44 & 1.35 \\
\hline $\mathrm{C} 5$ & $114 \times 3 \times 410$ & 600 & 120 & 50 & $\mathrm{C} 40$ & 3.6 & 1.61 & 1.21 \\
\hline C6 & $114 \times 3 \times 410$ & 600 & 120 & 100 & $\mathrm{C} 40$ & 3.6 & 1.69 & 1.29 \\
\hline $\mathrm{C} 7$ & $114 \times 3 \times 260$ & 600 & 120 & 0 & $\mathrm{C} 30$ & 2.3 & 1.41 & 1.77 \\
\hline $\mathrm{C} 8$ & $114 \times 3 \times 260$ & 600 & 120 & 50 & $\mathrm{C} 30$ & 2.3 & 1.45 & 1.59 \\
\hline C9 & $114 \times 3 \times 260$ & 600 & 120 & 100 & C30 & 2.3 & 1.66 & 1.44 \\
\hline $\mathrm{C} 10$ & $114 \times 3 \times 260$ & 20 & 0 & 0 & $\mathrm{C} 30$ & 2.3 & 0.61 & 1.24 \\
\hline $\mathrm{C} 11$ & $114 \times 3 \times 260$ & 200 & 120 & 0 & C30 & 2.3 & 0.88 & 1.58 \\
\hline $\mathrm{C} 12$ & $114 \times 3 \times 260$ & 400 & 120 & 0 & C30 & 2.3 & 1.25 & 2.07 \\
\hline $\mathrm{C} 13$ & $114 \times 3 \times 260$ & 800 & 120 & 0 & C30 & 2.3 & 1.84 & 3.83 \\
\hline $\mathrm{C} 14$ & $114 \times 3 \times 260$ & 20 & 0 & 50 & $\mathrm{C} 30$ & 2.3 & 0.62 & 0.95 \\
\hline $\mathrm{C} 15$ & $114 \times 3 \times 260$ & 200 & 120 & 50 & $\mathrm{C} 30$ & 2.3 & 0.89 & 2.12 \\
\hline $\mathrm{C} 16$ & $114 \times 3 \times 260$ & 400 & 120 & 50 & $\mathrm{C} 30$ & 2.3 & 1.32 & 2.01 \\
\hline $\mathrm{C} 17$ & $114 \times 3 \times 260$ & 800 & 120 & 50 & $\mathrm{C} 30$ & 2.3 & 2.07 & 3.79 \\
\hline $\mathrm{C} 18$ & $114 \times 3 \times 260$ & 20 & 0 & 100 & $\mathrm{C} 30$ & 2.3 & 0.65 & 1.25 \\
\hline C19 & $114 \times 3 \times 260$ & 200 & 120 & 100 & C30 & 2.3 & 0.95 & 1.40 \\
\hline $\mathrm{C} 20$ & $114 \times 3 \times 260$ & 400 & 120 & 100 & $\mathrm{C} 30$ & 2.3 & 1.41 & 2.63 \\
\hline $\mathrm{C} 21$ & $114 \times 3 \times 260$ & 800 & 120 & 100 & $\mathrm{C} 30$ & 2.3 & 2.37 & 2.75 \\
\hline $\mathrm{C} 22$ & $114 \times 3 \times 260$ & 600 & 30 & 0 & C30 & 2.3 & 1.04 & 0.67 \\
\hline $\mathrm{C} 23$ & $114 \times 3 \times 260$ & 600 & 60 & 0 & $\mathrm{C} 30$ & 2.3 & 1.18 & 0.97 \\
\hline $\mathrm{C} 24$ & $114 \times 3 \times 260$ & 600 & 30 & 50 & $\mathrm{C} 30$ & 2.3 & 1.14 & 0.72 \\
\hline $\mathrm{C} 25$ & $114 \times 3 \times 260$ & 600 & 60 & 50 & $\mathrm{C} 30$ & 2.3 & 1.42 & 1.17 \\
\hline C26 & $114 \times 3 \times 260$ & 600 & 30 & 100 & C30 & 2.3 & 1.25 & 1.55 \\
\hline $\mathrm{C} 27$ & $114 \times 3 \times 260$ & 600 & 60 & 100 & $\mathrm{C} 30$ & 2.3 & 1.61 & 1.39 \\
\hline
\end{tabular}

TABLE 2: Mix proportion of the recycled coarse aggregate concrete.

\begin{tabular}{|c|c|c|c|c|c|c|c|}
\hline Concrete type & $r(\%)$ & RCA $\left(\mathrm{kg} \cdot \mathrm{m}^{-3}\right)$ & Cement $\left(\mathrm{kg} \cdot \mathrm{m}^{-3}\right)$ & Sand $\left(\mathrm{kg} \cdot \mathrm{m}^{-3}\right)$ & NCA $\left(\mathrm{kg} \cdot \mathrm{m}^{-3}\right)$ & Water $\left(\mathrm{kg} \cdot \mathrm{m}^{-3}\right)$ & $f_{\mathrm{cu}}(\mathrm{MPa})$ \\
\hline \multirow{3}{*}{ C30 } & 0 & 0 & 513 & 474 & 1218 & 195 & 35.5 \\
\hline & 50 & 609 & 513 & 474 & 609 & 195 & 33.2 \\
\hline & 100 & 1218 & 513 & 474 & 0 & 195 & 31.1 \\
\hline \multirow{3}{*}{$\mathrm{C} 40$} & 0 & 0 & 454 & 595 & 1152 & 200 & 48.4 \\
\hline & 50 & 576 & 454 & 595 & 576 & 200 & 45.2 \\
\hline & 100 & 1152 & 454 & 595 & 0 & 200 & 40.3 \\
\hline
\end{tabular}

TABLE 3: Physical properties of RCA.

\begin{tabular}{lccccc}
\hline Grading $(\mathrm{mm})$ & Bulk density $\left(\mathrm{kg} / \mathrm{m}^{3}\right)$ & Apparent density $\left(\mathrm{kg} / \mathrm{m}^{3}\right)$ & Water absorption $(\%)$ & Silt content $(\%)$ & Crushing value $(\%)$ \\
\hline $5-20$ & 1385 & 2490 & 8.47 & 5.5 & 13.2 \\
\hline
\end{tabular}

$600^{\circ} \mathrm{C}$, and $800^{\circ} \mathrm{C}$, respectively. It is no doubt that the high temperature has an impact on the chemical adhesion and friction between the steel tube and recycled aggregate concrete, which leads to a radical reduction or enhancement of bond strength.

3.3. Effect of Exposure Period. The bond stress-slip curves of different exposure periods are shown in Figure 5. It can be seen that the curve of heated specimens with a shorter exposure period reaches the bond strength at peak slip values $S_{\mathrm{u}}$. On the contrary, the heated specimens with a longer exposure period have a larger peak slip and a longer descending branch. The effect of exposure period on bond strength of RCA concrete specimens are shown in Figure 6. As can be seen, the bond strength generally increases with the exposure period increases. The bond strengths of the specimens under an exposure period of $60 \mathrm{~min}$ are higher than those of $30 \mathrm{~min}$ by $12.8 \%, 24.5 \%$, and $29.0 \%$ for the RCA replacement ratios of $0 \%, 50 \%$, and $100 \%$, respectively, whereas those of $120 \mathrm{~min}$ are $34.9 \%, 27.5 \%$, and $33.2 \%$, respectively.

3.4. Effect of RCA Replacement Ratio. The bond stress-slip curves of the specimens with different RCA replacement 


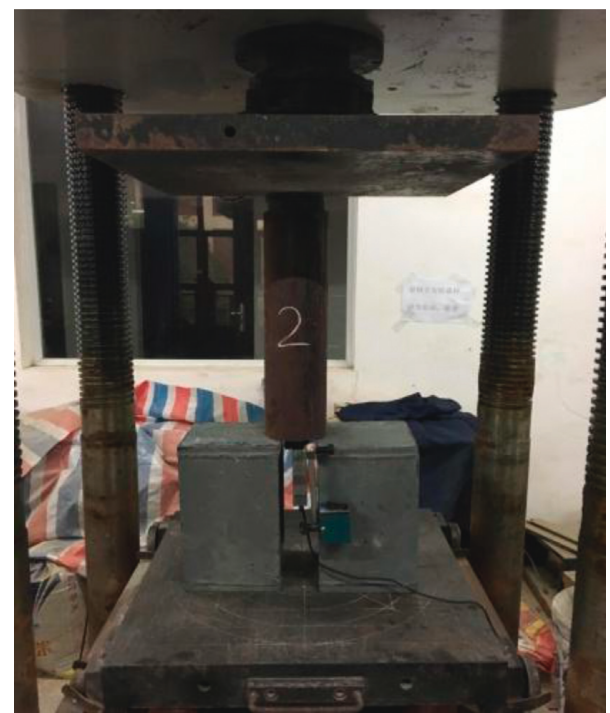

(a)

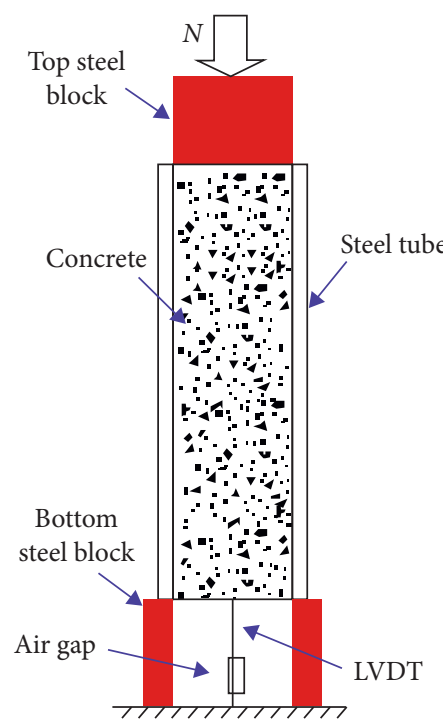

(b)

Figure 1: Test setup.

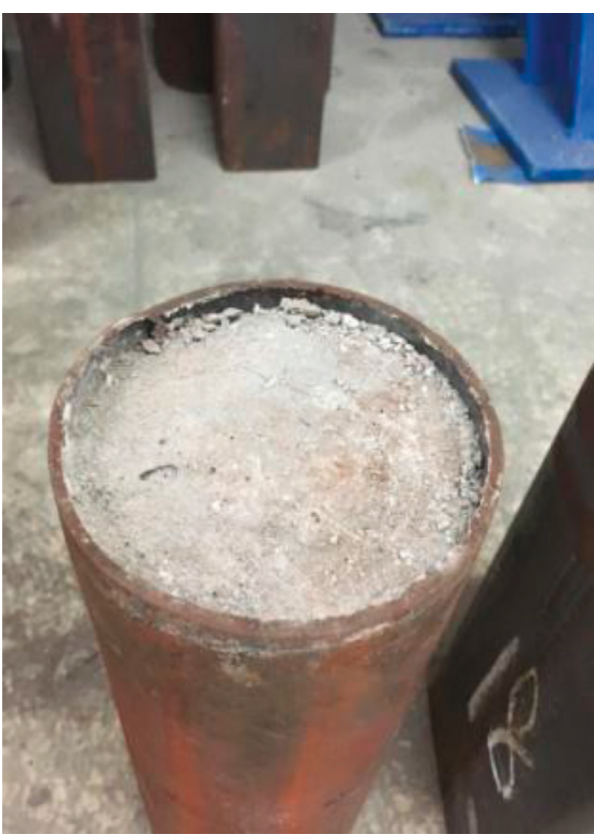

Figure 2: Typical failure mode.

ratios are shown in Figure 7. It is found that the RCA replacement ratios hardly influence the shape of the bond stress-slip curves. Additionally, the specimen with a higher replacement ratio is found to yield at a higher bond strength, but a smaller peak slip. The effect of RCA replacement ratio on the bond strength of RCA concrete specimens is shown in Figure 8. It can be concluded that the bond strength for the specimens at the same temperature increases as the RCA replacement ratio increases. For the exposure temperature of $200^{\circ} \mathrm{C}$, the bond strengths of the specimens with RCA replacement ratios of $0 \%, 50 \%$, and $100 \%$ are $0.88 \mathrm{MPa}$, $0.89 \mathrm{MPa}$, and $0.95 \mathrm{MPa}$, respectively. The increase ratio of the bond strength with RCA replacement ratios of $50 \%$ and

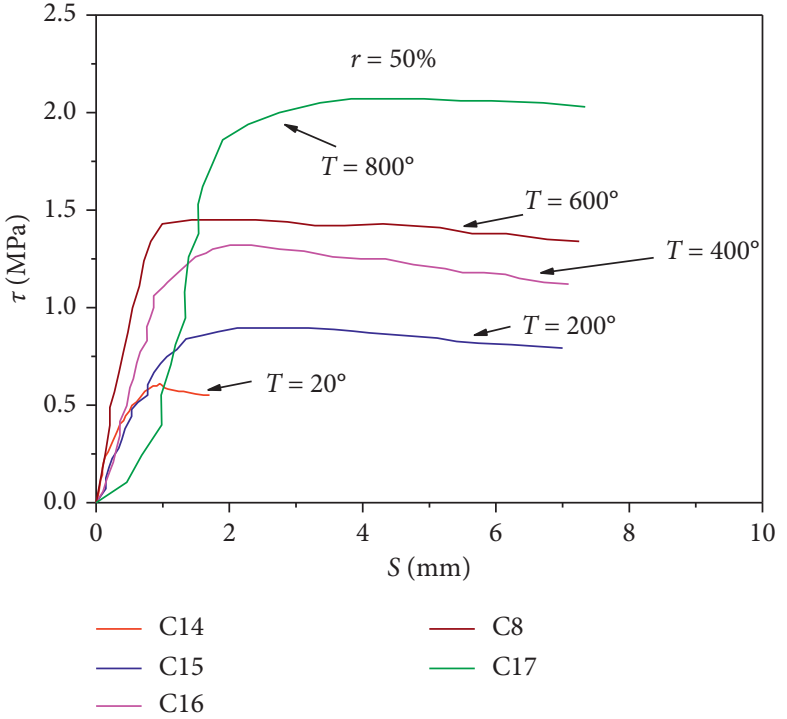

FIgURE 3: Typical bond stress-slip after exposure to different temperatures.

$100 \%$ to that of normal concrete (i.e., RCA replacement ratio is 0 ) for the specimens exposed to a temperature of $400^{\circ} \mathrm{C}$ is $5.5 \%$ and $13.0 \%$, respectively, which for the specimens exposed to temperatures of $600^{\circ} \mathrm{C}$ and $800^{\circ} \mathrm{C}$ are $2.9 \%$ and $18.1 \%$, and $12.5 \%$ and $28.8 \%$, respectively.

3.5. Effect of Concrete Strength. The influences of concrete strength on the bond stress-slip curves and the bond strength are given in Figures 9 and 10, respectively. Figure 9 suggests that specimens with different concrete strengths generally yield the bond stress-slip curves with similar sharp but different bond strengths and peak slips. The bond strengths with RCA replacement ratios of $0 \%, 50 \%$, and $100 \%$ for C30 specimens are $1.28 \mathrm{MPa}, 1.32 \mathrm{MPa}$, and 

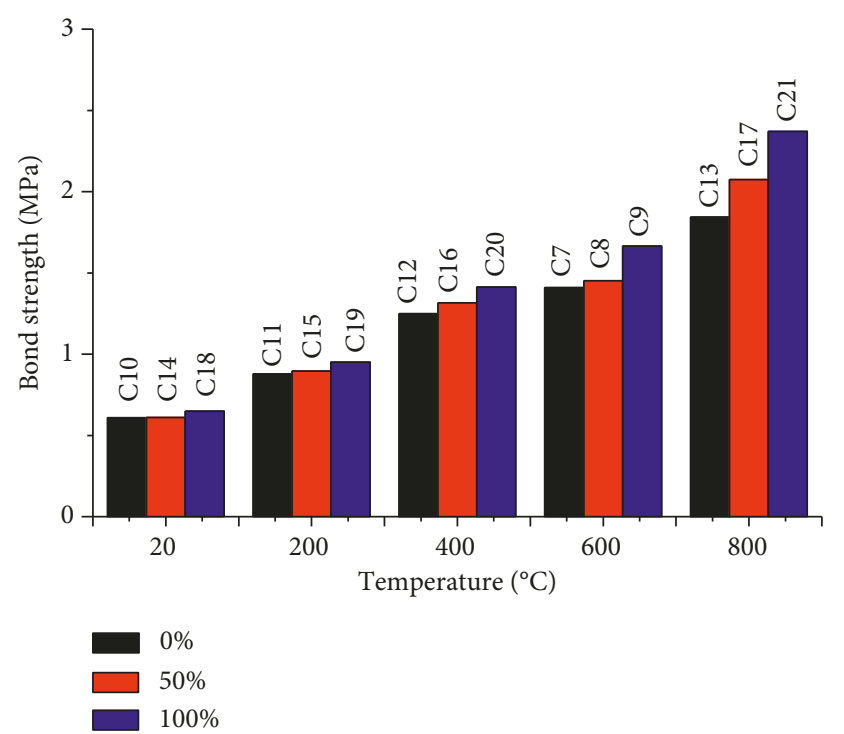

FiguRE 4: Effect of high temperatures on bond strength.

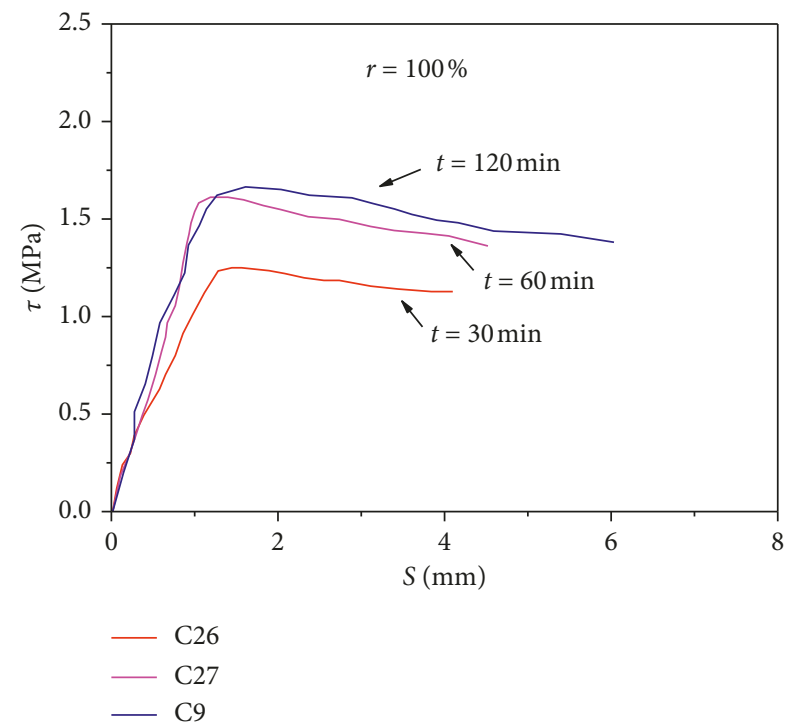

FIgURE 5: Typical bond stress-slip of different exposure periods.

$1.51 \mathrm{MPa}$, respectively, whereas for $\mathrm{C} 40$ specimens, they are $1.44 \mathrm{MPa}, 1.61 \mathrm{MPa}$, and $1.69 \mathrm{MPa}$, respectively. That is, the higher the concrete strength, the higher the bond strength, which can be clearly observed in Figure 10. This may be because the adhesion resistance and mechanical interlock at the interface between the steel tube and recycled coarse aggregate concrete increases when the concrete strength increases. In addition, the internal cracking of the test specimens is delayed as the tensile strength of the concrete increases.

3.6. Effect of Interface Length to Diameter Ratio. Figure 11 shows the bond stress-slip curves of different interface length-to-diameter ratios, $L_{\mathrm{e}} / D$. It can be seen that

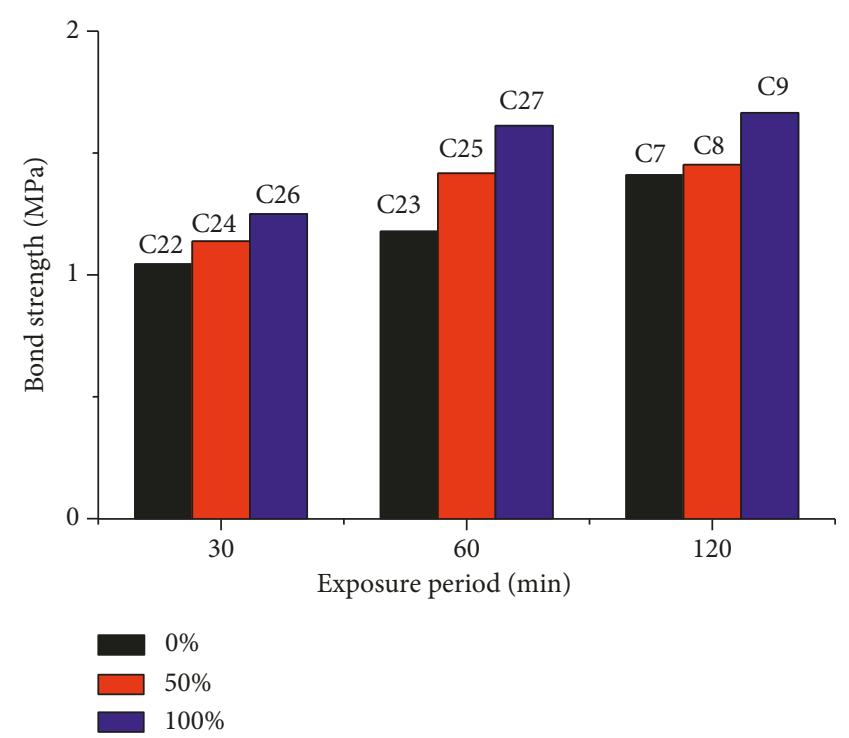

FIGURE 6: Effect of exposure periods on bond strength.

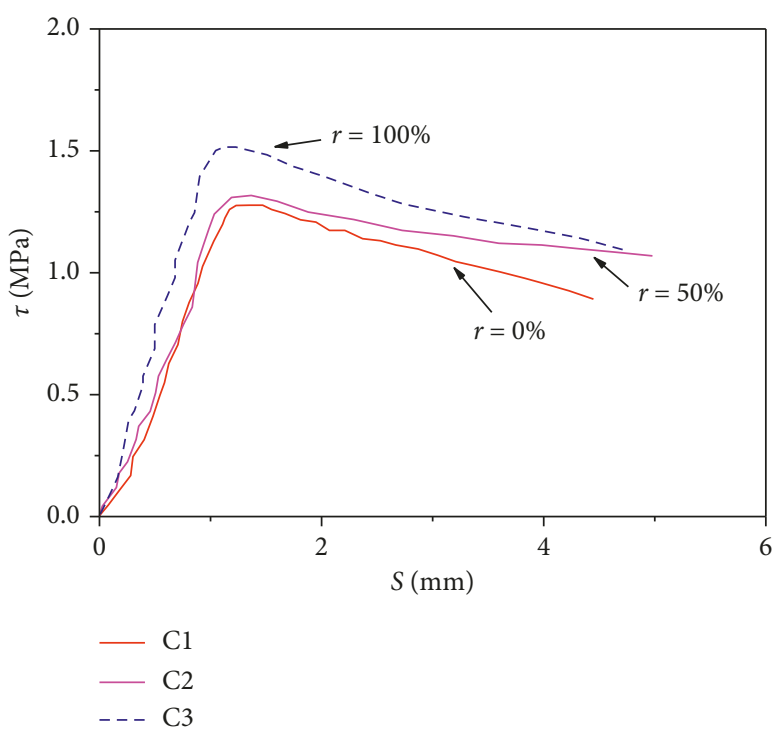

Figure 7: Typical bond stress-slip for different RCA replacement ratios.

$L_{\mathrm{e}} / D$ did not affect the basic shape of bond stress-slip curves. The effect of $L_{\mathrm{e}} / D$ on the bond strength of specimens is shown in Figure 12. It can be observed that the bond strength decreased with the increase in $L_{\mathrm{e}} / D$. This is because the bond strength is mainly provided by the steel-concrete interaction near the loaded end and the constraint ability for the specimens with smaller $L_{\mathrm{e}} / D$ is relatively good, thus resulting in a higher bond strength.

3.7. Modeling of the Bond Strength. To predict the bond strength between the circular steel tube and natural aggregate concrete at ambient temperature, several equations have proposed in previous studies. 


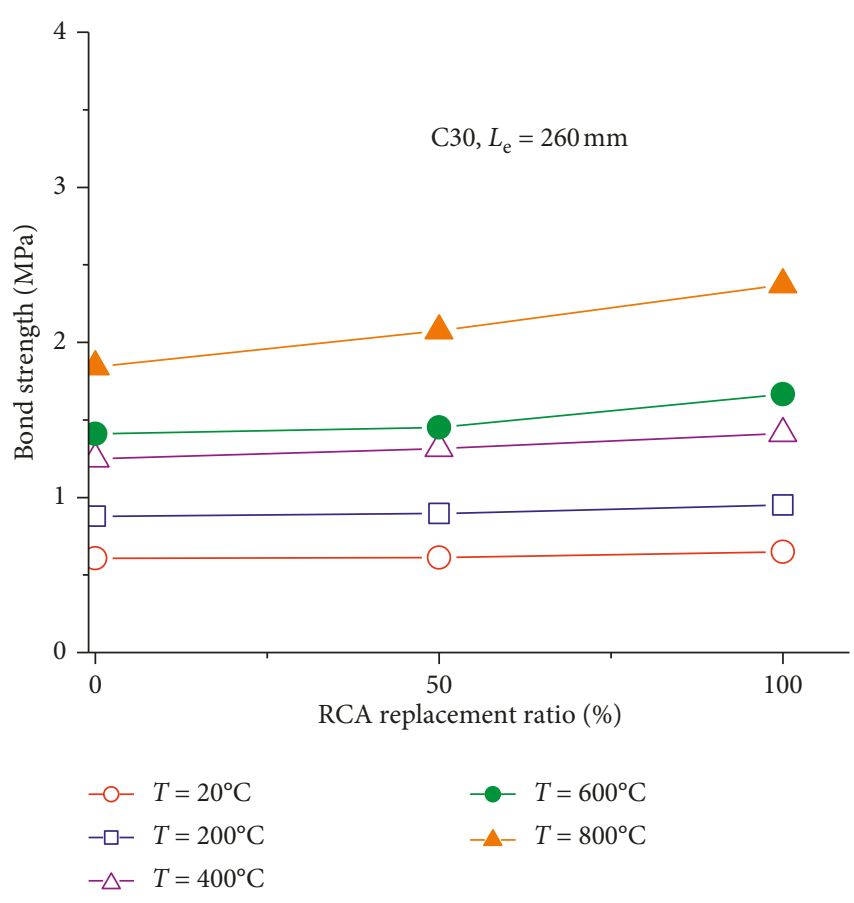

FIgURE 8: Effect of RCA replacement ratio on bond strength.

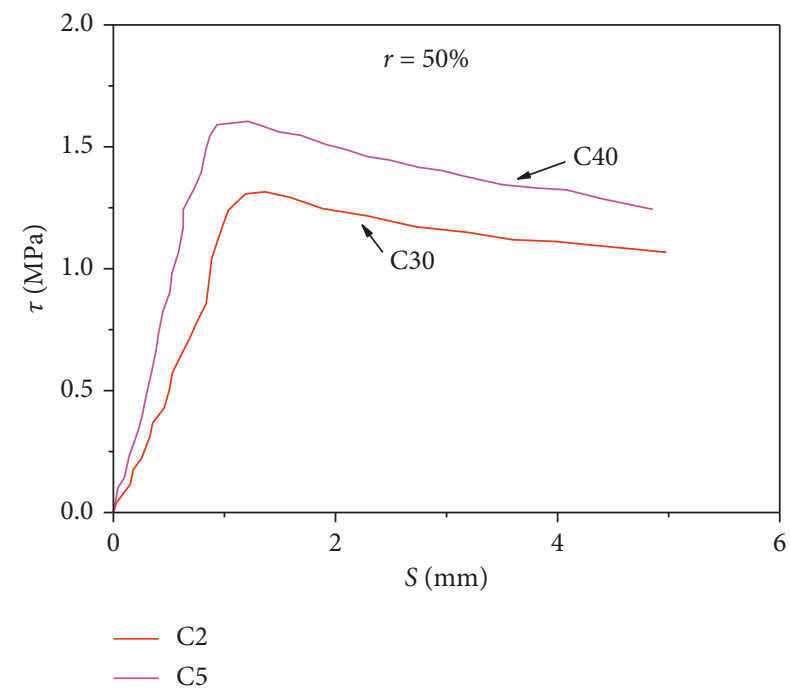

FIGURE 9: Typical bond stress-slip of different concrete strengths.

Cai [18] proposed an empirical formulation as follows:

$$
\tau_{\mathrm{u}}=0.1 f_{\mathrm{cu}}^{0.4},
$$

where $f_{\mathrm{cu}}$ is the cube compressive strength of the concrete, which is limited to the concrete type from C40 to C80.

The bond strength model of Gourley et al. [19] can be given as

$$
\tau_{\mathrm{u}}=2.109-0.026\left(\frac{D}{t}\right)
$$

where $D$ and $t$ are the external diameter and thickness of the circular steel tube, respectively.

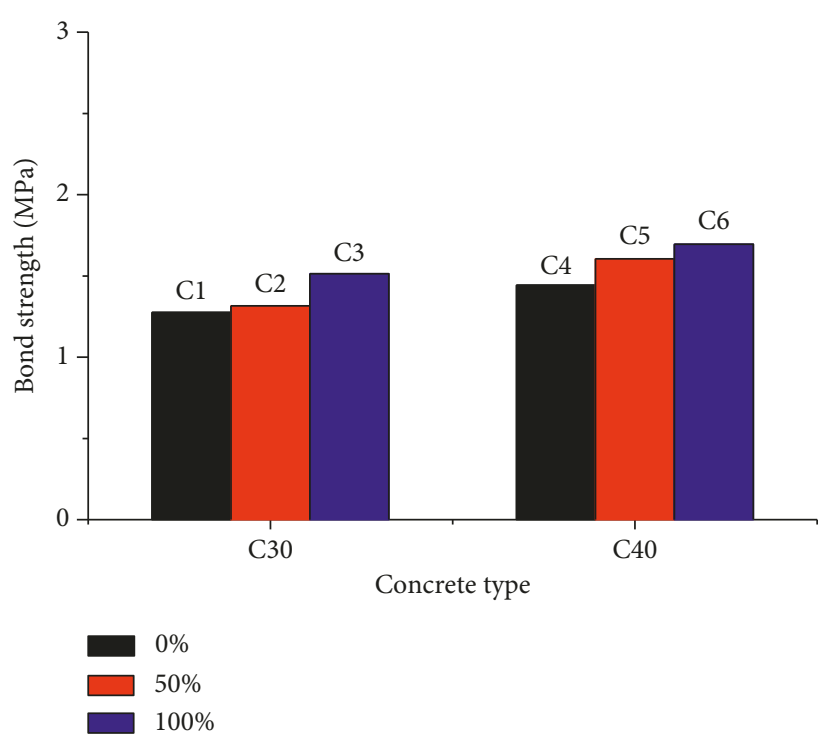

Figure 10: Effect of concrete strength on bond strength.

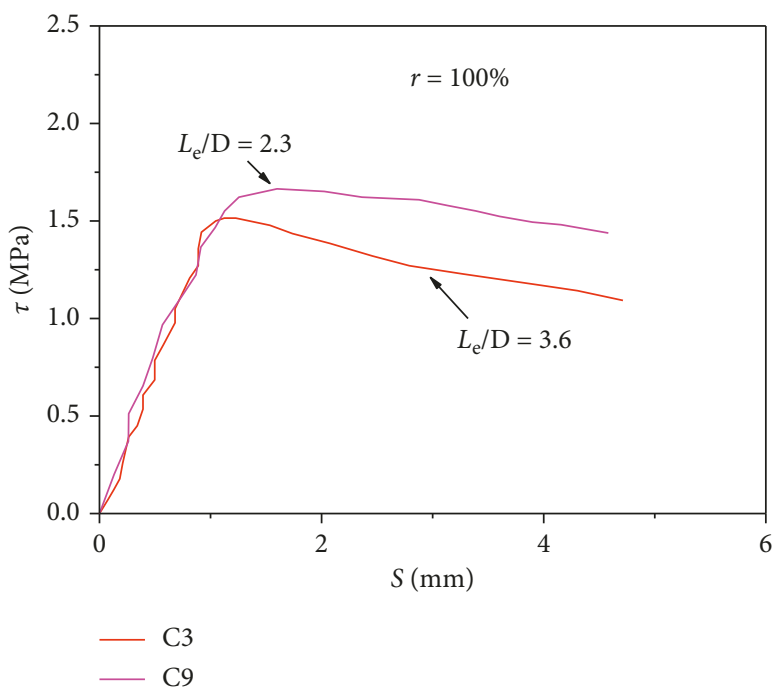

Figure 11: Typical bond stress-slip of different interface length-todiameter ratios.

Additionally, Yang and Han [20] proposed an expression for bond strength as

$$
\begin{aligned}
\tau_{\mathrm{u}} & =\left(0.00356 \cdot f_{\mathrm{cu}}+0.4\right) \cdot f(\lambda) \cdot f\left(\frac{D}{t}\right), \\
f(\lambda) & =1.36-0.09 \ln (\lambda), \\
f\left(\frac{D}{t}\right) & =1.35-0.09 \ln \left(\frac{D}{y}\right), \\
\lambda & =\frac{4 L_{\mathrm{e}}}{D},
\end{aligned}
$$

where $f_{\mathrm{cu}}$ is the cube compressive strength of the concrete, $D$ is the external diameter of the circular steel tube, $t$ is the 

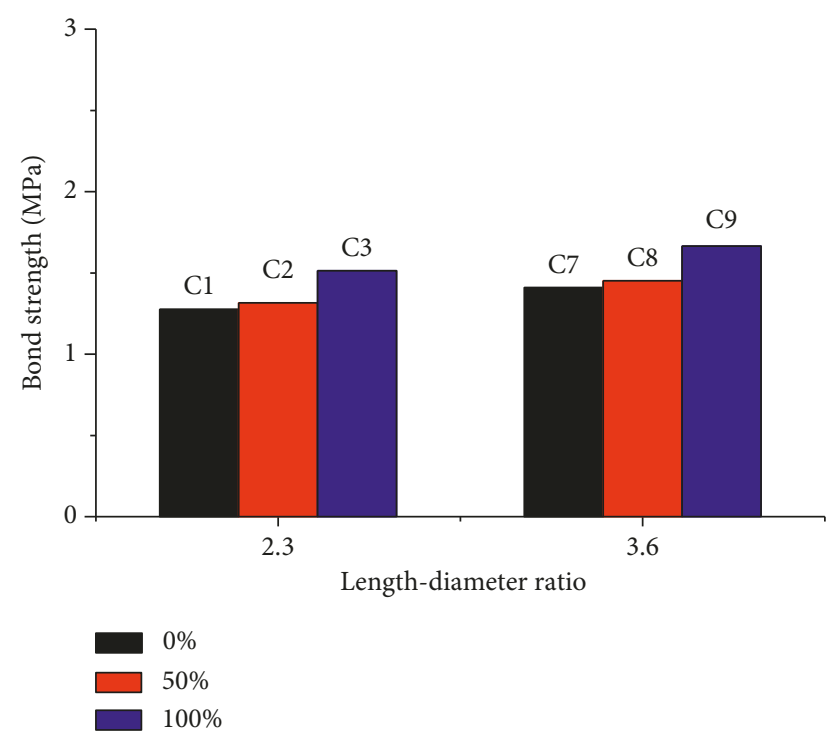

FIGURE 12: Effect of length-diameter ratio on bond strength.

wall thickness of the circular steel tube, and $L_{\mathrm{e}}$ is the length of the steel-concrete interface.

However, a model of the bond strength for the recycled coarse aggregate concrete and steel tube after exposure to high temperatures has not been proposed yet. Thus, a model to predict the bond strength between the recycled coarse aggregate concrete and steel tube after exposure to high temperatures is developed based on the results of the test in this study. This model is modified from that of Yang and Han [20], which can be given as

$$
\begin{aligned}
\tau_{\mathrm{u}}= & K_{\mathrm{T}} \cdot K_{\mathrm{t}}\left(0.00356 \cdot\left(1-0.221 r+0.534 r^{2}\right) \cdot f_{\mathrm{cu}}+0.4\right) \\
& \cdot f(\lambda) \cdot f\left(\frac{D}{t}\right), \\
K_{\mathrm{T}}= & 1-0.323 \frac{T-20}{800}+1.535\left(\frac{T-20}{800}\right)^{2}, \\
K_{\mathrm{t}}= & 1+0.567 \frac{t}{120}, \\
f(\lambda)= & 1.36-0.09 \ln (\lambda), \\
f\left(\frac{D}{t}\right)= & 1.35-0.09 \ln \left(\frac{D}{t}\right), \\
\lambda= & \frac{4 L_{\mathrm{e}}}{D},
\end{aligned}
$$

where $T$ is the temperature in ${ }^{\circ} \mathrm{C}, t$ is the exposure period in minute, $f_{\mathrm{cu}}$ is the cube compressive strength of the concrete, $D$ is the external diameter of the circular steel tube, $t$ is the wall thickness of the circular steel tube, and $L_{\mathrm{e}}$ is the length of the steel-concrete interface.

Table 4 shows the comparison of tested and calculated bond strength values. It can be seen that the developed model can predict the bond strength for the recycled coarse
TABLE 4: Summary of the calculated and the experimental bond strength.

\begin{tabular}{lccc}
\hline No. & $\tau_{\text {expu }}(\mathrm{MPa})$ & $\tau_{\text {calu }}(\mathrm{MPa})$ & Error $(\%)$ \\
\hline C1 & 1.28 & 1.40 & 10.14 \\
C2 & 1.32 & 1.41 & 7.37 \\
C3 & 1.51 & 1.50 & 0.30 \\
C4 & 1.44 & 1.53 & 5.96 \\
C5 & 1.61 & 1.55 & 4.09 \\
C6 & 1.69 & 1.67 & 1.27 \\
C7 & 1.41 & 1.53 & 9.13 \\
C8 & 1.45 & 1.55 & 6.51 \\
C9 & 1.66 & 1.65 & 0.73 \\
C10 & 0.61 & 0.62 & 2.64 \\
C11 & 0.88 & 0.98 & 11.81 \\
C12 & 1.25 & 1.17 & 6.51 \\
C13 & 1.84 & 2.09 & 13.81 \\
C14 & 0.61 & 0.63 & 2.69 \\
C15 & 0.89 & 0.99 & 10.29 \\
C16 & 1.32 & 1.17 & 10.88 \\
C17 & 2.07 & 2.11 & 1.70 \\
C18 & 0.65 & 0.67 & 3.25 \\
C19 & 0.95 & 1.06 & 11.09 \\
C20 & 1.41 & 1.25 & 11.25 \\
C21 & 2.37 & 2.25 & 4.94 \\
C22 & 1.04 & 1.12 & 7.34 \\
C23 & 1.18 & 1.26 & 6.94 \\
C24 & 1.14 & 1.13 & 1.02 \\
C25 & 1.42 & 1.27 & 10.59 \\
C26 & 1.25 & 1.20 & 3.63 \\
C27 & 1.61 & 1.35 & 16.03 \\
\hline
\end{tabular}

aggregate concrete and circular steel tube after exposure to high temperatures reasonably well.

\section{Conclusions}

Based on the experimental results presented in the paper, the following conclusions can be drawn:

(i) The shape of the bond stress-slip curve for RACFST is influenced by only the temperature and exposure period, which is hardly affected by RCA replacement ratio, concrete strength, and/or lengthto-diameter ratio.

(ii) Bond strength between RAC and steel tubes after exposure to high temperatures is influenced by all the parameters. Generally, bond strength increases with increasing temperature, exposure period, RCA replacement ratio, and concrete strength but decreases with increasing interface length-to-diameter ratio.

(iii) A bond strength model is proposed to predict the bond strength between RAC and steel tubes, which is found to perform well with the experimental results.

To carry out the bond behavior of CRACFST columns after exposure to elevated temperatures, further research is needed on the model for bond stress-slippage with more test results. 


\section{Data Availability}

The data used to support the findings of this study are included within the article.

\section{Conflicts of Interest}

The authors declare that they have no conflicts of interest regarding the publication of this paper.

\section{Acknowledgments}

This work was supported by the Chinese National Natural Science Foundation (no. 51868001), the Natural Science Foundation of Jiangxi Province for Distinguished Young Scholars (no. 20162BCB23051), the Natural Science Foundation of Jiangxi Province (no. 20171BAB206053), and the Hundred People Voyage Project of Jiangxi Province, which are gratefully acknowledged.

\section{References}

[1] G. Ren, H. Shang, P. Zhang, and T. Zhao, "Bond behaviour of reinforced recycled concrete after rapid freezing-thawing cycles," Cold Regions Science and Technology, vol. 157, pp. 133-138, 2019.

[2] R. Kurda, J. de Brito, and J. D. Silvestre, "Water absorption and electrical resistivity of concrete with recycled concrete aggregates and fly ash," Cement and Concrete Composites, vol. 95, pp. 169-182, 2019.

[3] J. Thomas, N. N. Thaickavil, and P. M. Wilson, "Strength and durability of concrete containing recycled concrete aggregates," Journal of Building Engineering, vol. 19, pp. 349-365, 2018.

[4] A. Wongkvanklom, P. Posi, B. Khotsopha et al., "Structural lightweight concrete containing recycled lightweight concrete aggregate," KSCE Journal of Civil Engineering, vol. 22, no. 8, pp. 3077-3084, 2018.

[5] J. F. Liang, E. Wang, X. Zhou, and Q. L. Le, "Influence of high temperature on mechanical properties of concrete containing recycled fine aggregate," Computers and Concrete, vol. 21, no. 1, pp. 87-94, 2018.

[6] B. M. Vinay Kumar, H. Ananthan, and K. V. Balaji, "Experimental studies on utilization of recycled coarse and fine aggregates in high performance concrete mixes," Alexandria Engineering Journal, vol. 57, no. 3, pp. 1749-1759, 2018.

[7] S. Sadati and K. H. Khayat, "Restrained shrinkage cracking of recycled aggregate concrete," Materials and Structures, vol. 50, no. 4, pp. 17-27, 2017.

[8] K. Wu, F. Chen, C. Xu, S.-Q. Lin, and Y. Nan, "Internal curing effect on strength of recycled concrete and its enhancement in concrete-filled thin-wall steel tube," Construction and Building Materials, vol. 153, pp. 824-834, 2017.

[9] Y.-F. Yang and G.-L. Ma, "Experimental behaviour of recycled aggregate concrete filled stainless steel tube stub columns and beams," Thin-Walled Structures, vol. 66, pp. 62-75, 2013.

[10] Y.-Y. Wang, Y. Geng, Y.-C. Chang, and C.-J. Zhou, "Timedependent behaviour of recycled concrete filled steel tubes using RCA from different parent waste material," Construction and Building Materials, vol. 193, pp. 230-243, 2018.

[11] W. Li, Z. Luo, C. Wu, and W. H. Duan, "Impact performances of steel tube-confined recycled aggregate concrete (STCRAC) after exposure to elevated temperatures," Cement and Concrete Composites, vol. 86, pp. 87-97, 2018.

[12] J. Chen, Y. Wang, C. W. Roeder, and J. Ma, "Behavior of normal-strength recycled aggregate concrete filled steel tubes under combined loading," Engineering Structures, vol. 130, pp. 23-40, 2017.

[13] Z. Tao, T.-Y. Song, B. Uy, and L.-H. Han, "Bond behavior in concrete-filled steel tubes," Journal of Constructional Steel Research, vol. 120, pp. 81-93, 2016.

[14] J.-Y. Hwang, H.-G. Kwak, and Y. Kwon, “A numerical model for considering the bond-slip effect in axially loaded circular concrete-filled tube columns," Advances in Structural Engineering, vol. 21, no. 12, pp. 1923-1935, 2018.

[15] Y. Chen, R. Feng, Y. Shao, and X. Zhang, "Bond-slip behaviour of concrete-filled stainless steel circular hollow section tubes," Journal of Constructional Steel Research, vol. 130, pp. 248-263, 2017.

[16] Z. Tao, L.-H. Han, B. Uy, and X. Chen, "Post-fire bond between the steel tube and concrete in concrete-filled steel tubular columns," Journal of Constructional Steel Research, vol. 67, no. 3, pp. 484-496, 2011.

[17] Z. Chen, J. Xu, Y. Liang, and Y. Su, "Bond behaviors of shape steel embedded in recycled aggregate concrete and recycled aggregate concrete filled in steel tubes," Steel and Composite Structures, vol. 17, no. 6, pp. 929-949, 2014.

[18] S. H. Cai, Modern Times Structures of Concrete Filled Steel Tube, China Communications Press, Beijing, China, 2003, in Chinese.

[19] B. C. Gourley, C. Tort, J. F. Hajjar, and P. H. Schiller, “A synopsis of studies of the monotonic and cyclic behavior of concrete-filled steel tube beam-columns," Structural Engineering Report, Department of Civil and Environmental Engineering, University of Illinois at Urbana Champaign, Urbana, IL, USA, 2008.

[20] Y. F. Yang and L. H. Han, "Research on bond behavior between steel and concrete of self compacting concrete filled steel tubes with rectangular sections," Industrial Construction, vol. 36 , no. 11 , pp. 32-36, 2006, in Chinese. 


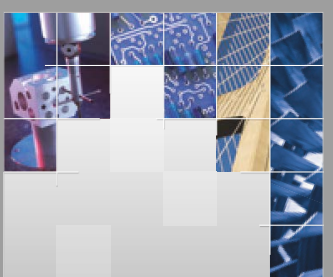

\section{Enfincering}
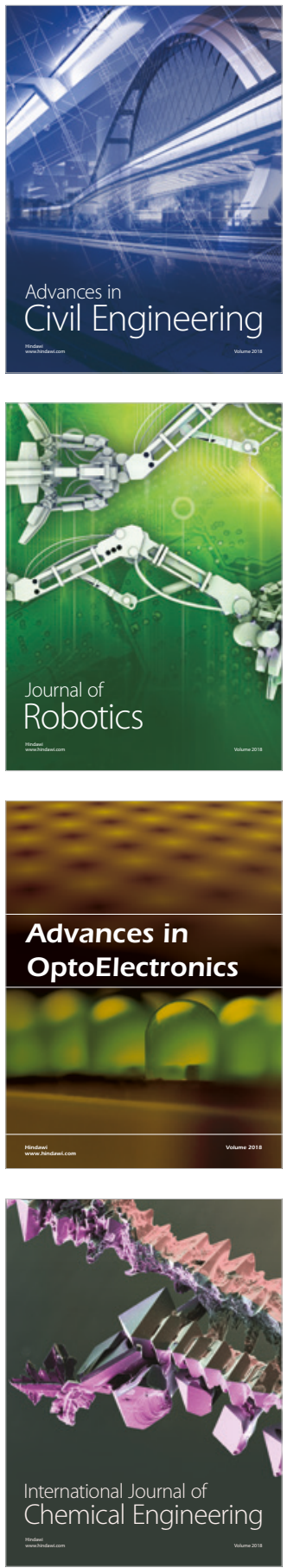

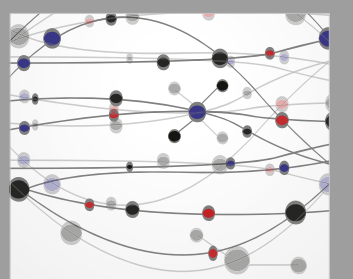

\section{Rotating \\ Machinery}

The Scientific World Journal

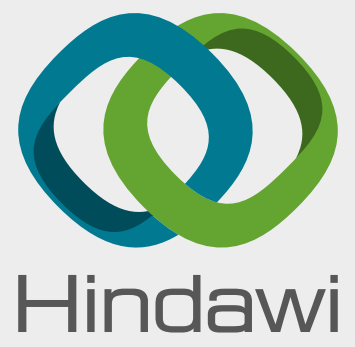

Submit your manuscripts at

www.hindawi.com
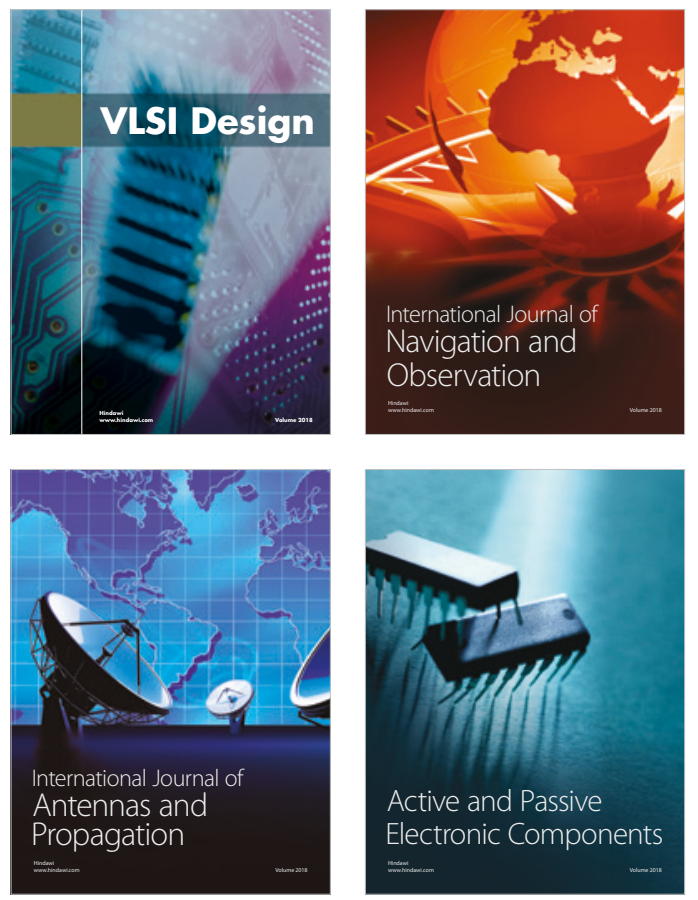
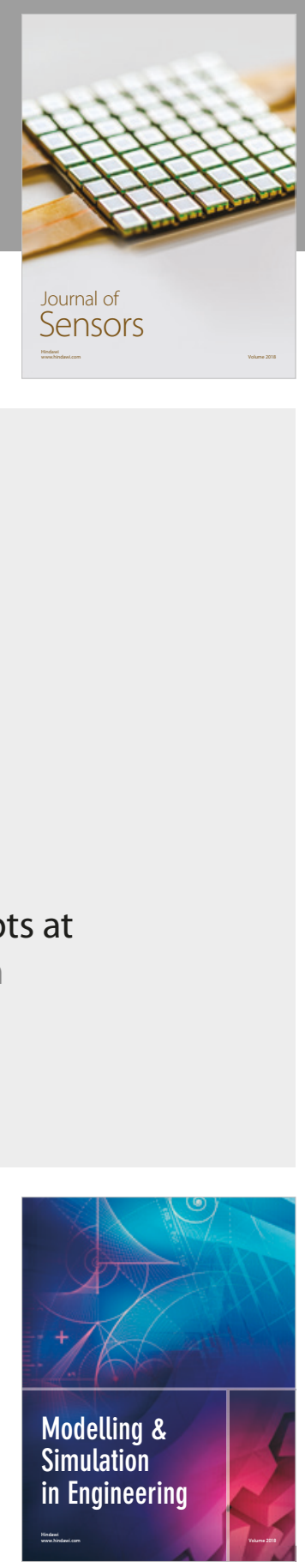

\section{Advances \\ Multimedia}
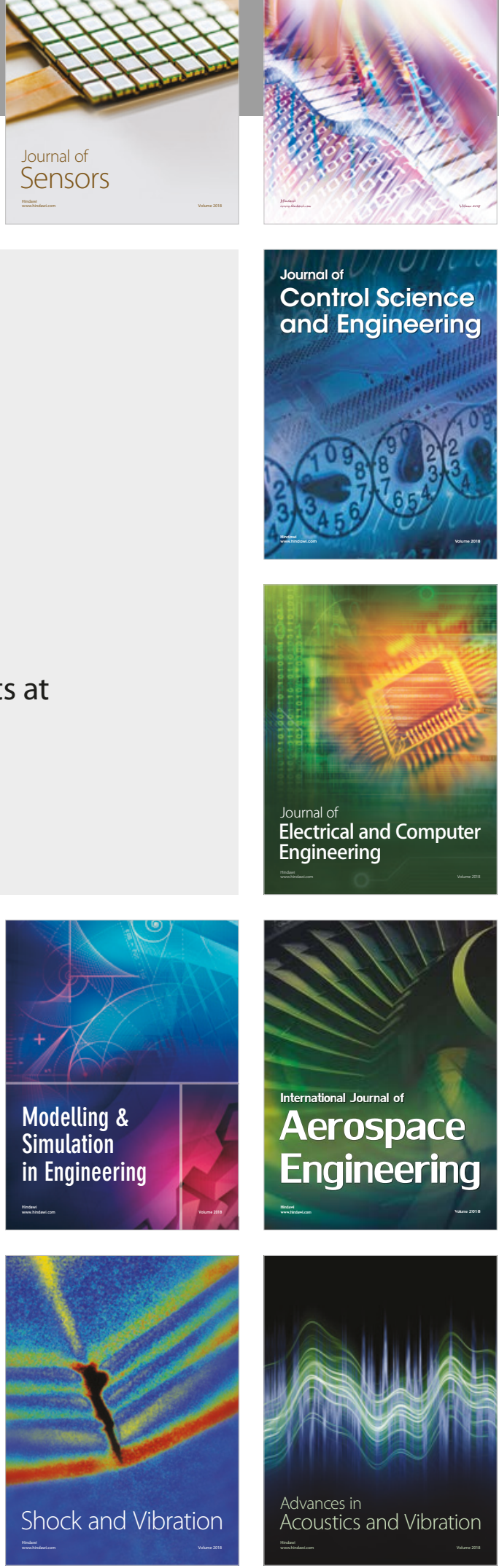